“(C) 2015 IEEE. Personal use of this material is permitted. Permission from IEEE must be obtained for all other uses, in any current or future media, including reprinting/republishing this material for advertising or promotional purposes, creating new collective works, for resale or redistribution to servers or lists, or reuse of any copyrighted component of this work in other works." 


\section{An Evaluation of the Goal-Oriented Approaches for Modelling Strategic Alignment Concept}

\author{
Abdul Babar, Bernard Wong \\ Faculty of Engineering and Information Technology \\ University of Technology Sydney \\ Sydney, Australia \\ \{abdul.babar, Bernard.Wong\}@uts.edu.au
}

\author{
Asif Qumer Gill \\ Discipline of Business Information Systems \\ University of Sydney Business School \\ Sydney, Australia \\ asif.qumer@sydney.edu.au
}

\begin{abstract}
Several frameworks have been proposed in Requirements Engineering (RE) discipline that use goaloriented approach to model the concept of strategic alignment. Understanding the concept of strategic alignment from the perspective of Management Information Systems (MIS) discipline and evaluating goal-oriented approaches in the context of strategic alignment appear to be the fundamental weakness in the RE frameworks that claim to model strategic alignment. In this research we developed a list of constructs by analysing the concept of strategic alignment embedded in strategy map which is one of the widely used frameworks to develop strategic alignment in MIS discipline. In this regard we analysed details of a case study conducted to develop strategic alignment. Against the identified list of constructs we evaluated five well-known goal-oriented approaches and presented their level of effectiveness to model the concept of strategic alignment.
\end{abstract}

Keywords: goal-oriented approaches, Requirements Engineering, business IT alignment

\section{INTRODUCTION}

The concept of goal modelling has been widely used in Requirements Engineering (RE) practices for system development - also known as goal-oriented requirements engineering [1]. A goal-oriented approach helps to analyse the ' $w h y$ ' aspect of a system (why a certain functionality is needed?) in addition to the 'what' aspect of a system (what a system needs to do?) [2, 3]. A number of goal-oriented approaches have been introduced in RE discipline over a period of time, which can broadly be divided into early and late-requirements modelling approaches [4]. A laterequirements modelling approach (e.g. KAOS) focuses on the future objectives and how they may be operationalised in terms of system components [3]; whereas an earlyrequirements modelling approach focuses on the analysis of stakeholder's needs and interests in terms of strategic intents, motivations and rationales [5, 6]. Use of goal-oriented approaches to model the concept of strategic alignment is new. Proposed frameworks use goal-oriented approaches to resolve any conflicts in the early stages of the Information System (IS) development lifecycle [7].

It has been suggested that aligning IS/IT with business strategy (in other words strategic alignment) has been topranking concern of business executive in the last two decades requiring deeper analysis of both business and IT domains [8]. Strategic alignment phenomenon can be described in terms of stakeholders and relationships among them for the strategic intents and desires of the firm to be achieved [9]. Originally strategic alignment phenomenon belongs to MIS discipline and it has recently been explored in RE discipline attempting to address the long-standing issue of aligning IT with business. Predominantly goal-oriented concepts have been used to propose frameworks that model the concept of strategic alignment [10-12]. Practical use of these frameworks appears to be limited $[10,11]$. Two fundamental weaknesses have been observed

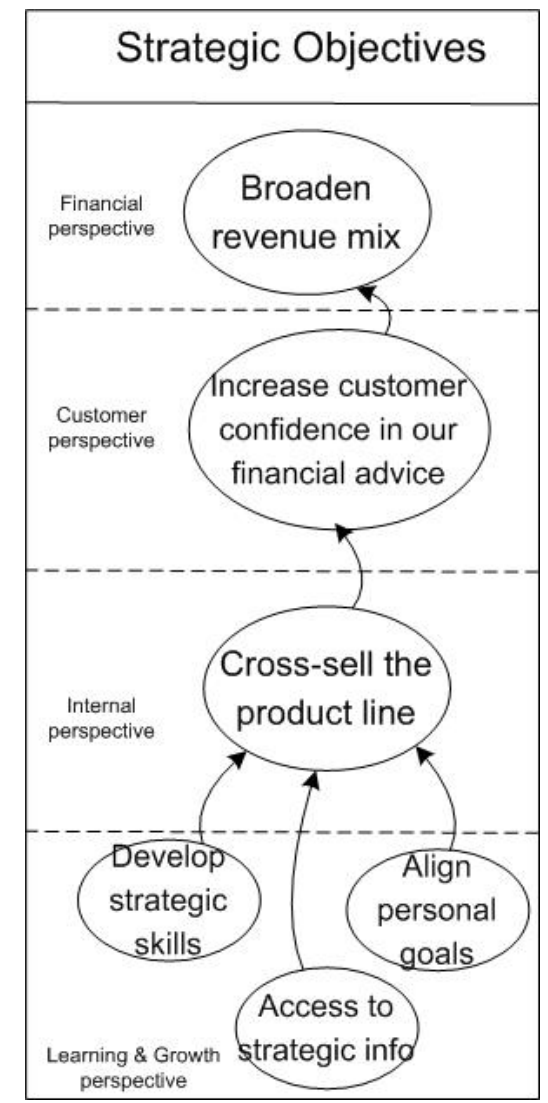

Figure 1. Concept of strategy map for cross-sell [9] 
in the frameworks: (1) strategic alignment concept may not be fully understood in the context of MIS discipline and (2) there is superficial approach in using goal-oriented concepts by not providing critical analysis of goal-oriented approaches before going to use one to model strategic alignment. Critical analysis of goal-oriented approaches against the concept of strategic alignment can provide a strong base on which the developed model may be viable. Therefore, we suggest that there is a need of comparative and critical analysis of goaloriented approaches against the concept of strategic alignment. It is anticipated that this comparative analysis would aid in understanding the capability of the goaloriented approaches used in modelling strategic alignment. However, the question is: how can we compare goaloriented approaches for modelling the concept of strategic alignment?

One way to do this is to use the concept of strategy map [9], which has evolved from balanced scorecard. It is one of the widely used frameworks that have been used to capture the holistic-view of strategic alignment. In the holistic-view, strategy map shows cause-and-effect relationships among the strategic objectives identified in four perspectives; financial, customer, internal and learning \& growth (see Figure 1). These four perspectives are the core aspects of strategic alignment which must be considered when describing the concept of strategic alignment. Therefore we use strategy map as a reference point to understand strategic alignment concept and evaluate modelling capability of goal-oriented approaches for strategic alignment. In this regard it is imperative that the constructs of strategy map and goaloriented approaches are identified and compared before deciding on an appropriate modelling approach. To identify a list of constructs of strategic alignment necessary to be modelled we used details of a case study conducted by Kaplan \& Norton in which they developed strategy map for Consumer Bank. The rest of the paper is as follows: section II discusses strategy map concept by analysing Consumer Bank case study and propose a list of modelling requirements. Section III presents overview of the major goal-oriented approaches. Section IV provides discussion on the effectiveness of goal-oriented approaches and conclusion of the paper is provided in section $\mathrm{V}$.

\section{The Concept of Strategic Alignment}

In the last more than two decades, MIS discipline has consistently reported on aligning IT with business as topranking concern for business executives [8]. Business executives have been exploring different ways of aligning IT with business to achieve strategic intent/s. Therefore, we consider that the concept of strategic alignment primarily belongs to MIS discipline. Thus the concept of strategic alignment below has been described from the perspective of MIS discipline.

The term "strategic alignment" means an effective integration of computer technologies into the fabric of firm's business processes to attain benchmarked business performance $[9,13]$. Generally speaking, firm's business executives expect from $I T$ (e.g. applications and networks) to support their internal and external business processes and executives want to know what exactly the business value in terms of financial and customer value they will achieve [14]. Aiming at business value targets, business executives with the help of IT executives define their long and short term financial and customer value targets but they want them precisely be defined in their perspectives which are generally driven from the firm's vision [9, 15]. The purpose of involving IT executives in defining financial and customer value is to make sure that IT executives understand the value targets and $\mathrm{s} /$ he should explain to business executives which processes are critical from IT support perspective to achieve the value targets. So, the primary components/perspectives of business IT alignment are financial targets, customer value propositions, strategic processes and IT.

A firm can have several types of key processes. Generally firms use value disciplines typology to categorise processes into three types - operational excellence, customer intimacy and innovation [16]. Operationally excellent firms focus on processes related to supplier relationships, production and operations while in customer intimate strategy firms concentrate on processes concerning marketing \& sales and customer relationship. For product leadership firms emphasise on processes related to products and services enhancement [13]. Generally business executives would like to know from IT executives which category of these three types of processes will be focused for IT use to realise value targets, though some firms can target more than one category of processes depending on firm's business aspiration. IT use for such processes means installation of IT applications and infrastructures [17] where IT organisation ensures that the applications are well integrated into firms overall website architecture. For each core process a specialist role must be identified which are considered responsible for effective execution of the processes contributing to the achievement of financial and customer value targets [9].

From this analysis it appears that the concept of strategic alignment can primarily be divided in four perspectives: financial value, customer value, processes and computer technology. Targets in these four perspectives be clearly identified and they should be precisely defined.

Strategy map is a strategic alignment concept mainly referring to four perspectives when used to develop strategic alignment as shown in Figure 1. Kaplan \& Norton 2004 [9] who are the inventor of strategy map conducted a case study on strategic alignment that has been described in [9] and it spans across many pages such as page no. 207, 261, 375. We analysed the textual description of the case study and extracted all the important constructs of strategy map. The details of the case study helped us to understand the principles behind the constructs. We developed a list of all the important constructs of strategy map and provided basic principles behind the constructs in Table I. 
TABLE I.

STRATEGY MAP CONSTRUCTS AND THEIR BASIC PRINCIPLES

\begin{tabular}{|c|c|c|}
\hline Code & Name & Basic principles of the constructs \\
\hline SM1 & Perspective & $\begin{array}{l}\text { Perspective refers to a firm's strategic view in terms of conceptual elements (e.g. goals and resources) } \\
\text { pertinent to a particular domain of concern. Strategy map consisting of four perspectives describes value } \\
\text { creating strategy in terms of objectives which provides basis for executives to discuss the directions and } \\
\text { priorities of their enterprise [9]. }\end{array}$ \\
\hline SM2 & $\begin{array}{l}\text { Financial } \\
\text { perspective }\end{array}$ & $\begin{array}{l}\text { Financial perspective describes how an enterprise intends to create sustainable growth in shareholder } \\
\text { value. In financial perspective, strategy map presents cost reduction and productivity improvement in } \\
\text { terms of short term objectives as well as profitable revenue growth targets in terms of long terms } \\
\text { financial objectives to realise sustainable growth in shareholder value [9]. So basically in the financial } \\
\text { perspective firm's financial targets are established which are precise in nature and can be achieved } \\
\text { through multiple means. }\end{array}$ \\
\hline SM3 & $\begin{array}{l}\text { Customer } \\
\text { perspective }\end{array}$ & $\begin{array}{l}\text { Customer perspective is used to describe customer value propositions (CVPs) which can be understood } \\
\text { in terms of customer's satisfaction with firm's products and services. Customer satisfaction which is the } \\
\text { mission and purpose of every business can be achieved through clear identification of value proposition } \\
\text { offered to please customers. } \\
\text { Generally low price and high quality of products and services are the targeted CVPs however for } \\
\text { Consumer Bank case study, we find integrated offerings, credibility of products and services and } \\
\text { helping customers to develop and implement their financial plans are also CVPs in addition to price and } \\
\text { quality. These propositions can generally be described as qualitative and quantitative values. }\end{array}$ \\
\hline SM4 & $\begin{array}{l}\text { Internal } \\
\text { perspective }\end{array}$ & $\begin{array}{l}\text { Internal perspective presents critical processes necessary to deliver differentiating value proposition } \\
\text { and shareholder value through revenue growth and productivity. These critical few processes which are } \\
\text { called strategic themes have quantitative values. For Consumer Bank case study, for example, strategic } \\
\text { theme minimize problems has a target of achieving reduction in errors by } 0.1 \% \text {. Therefore, critical few } \\
\text { processes in terms of strategic themes are benchmarked by Consumer Bank and we consider them as } \\
\text { quantitative goals. However, there are many activities encompassing learning \& growth perspective } \\
\text { which are described as sub-processes in strategy map create value in some way. We refer to these sub- } \\
\text { processes as activities which are performed to achieve strategic theme-related benchmarks. }\end{array}$ \\
\hline SM5 & $\begin{array}{l}\text { Learning \& } \\
\text { growth } \\
\text { perspective }\end{array}$ & $\begin{array}{l}\text { Learning \& growth perspective describe how people as human capital and technology as } \\
\text { Information Capital (IC) and relationships among people as organisational captial support firm's } \\
\text { strategy. Value of these assets/resources can be driven from their ability to help the organisation to } \\
\text { implement its strategy. Human capital refers to specialist roles required to execute strategic processes in } \\
\text { internal perspective. Note, strategy map of Consumer Bank not only has described specialist roles } \\
\text { required to execute processes in internal perspective but also has described generic roles necessary for } \\
\text { other three perspectives such as financial advisor for CVPs in customer perspective. Therefore, we } \\
\text { consider representation of stakeholders for all perspective and relationships among them is imperative. } \\
\text { Technology infrastructure used to support activities has consistently been called as asset/resource in the } \\
\text { MIS literature [17]. Therefore, we need to represent technology as asset/resource and people as roles for } \\
\text { all four perspectives. Organisational capital is also part of learning and growth perspective referring to } \\
\text { social dimension of strategic alignment. }\end{array}$ \\
\hline SM6 & $\begin{array}{l}\text { Classification of } \\
\text { objectives }\end{array}$ & $\begin{array}{l}\text { Consumer Bank case study presents strategic objectives for all four perspectives. However these } \\
\text { objectives are different in nature. For example Consumer Bank intends to achieved productivity and } \\
\text { growth targets to realise shareholders value, in this case shareholders target is strategic intent however } \\
\text { productivity and growth targets are objectives to achieve strategic intent. So, classification of targets for } \\
\text { all four perspectives in terms of intent/s and their rationale is necessary. }\end{array}$ \\
\hline SM7 & $\begin{array}{l}\text { Cause and } \\
\text { effect } \\
\text { relationship }\end{array}$ & $\begin{array}{l}\text { Cause-and-effect relationships between four perspectives are established to show that the support of } \\
\text { human capital and IC for internal processes can lead to achieve customer and shareholder value targets. } \\
\text { Establishing relationships among the perspectives mean to facilitate discussion among executives in } \\
\text { terms of linkages among objectives and human capital needed for them. Kaplan \& Norton } 2004 \\
\text { considers visual representation of linkages as a big insight to executives. }\end{array}$ \\
\hline SM8 & $\begin{array}{l}\text { Objectives to } \\
\text { achieve } \\
\text { strategic intent }\end{array}$ & $\begin{array}{l}\text { Objectives to achieve strategic intent is the concept as SM6 - Consumer Bank strategy map targets can } \\
\text { be classified into intents and rationales - rationales are facilitated to achieve intents. }\end{array}$ \\
\hline SM9 & $\begin{array}{l}\text { Relationships } \\
\text { strengths }\end{array}$ & $\begin{array}{l}\text { Relationships strengths objectives in each perspective which drive to achieve strategic intent have } \\
\text { various types of relationships and these relationships have various degrees of strengths. For example, } \\
\text { sub-objective cost per customer be reduced is a sole contributor to productivity objectives as compared } \\
\text { to the sub-objectives - revenue per customer be increased and high value customers be added and } \\
\text { retained for growth objective. So these relationships should be modelled differently. In another example, } \\
\text { sub-goals - price and quality contribute to credibility of services goal, in this case it is not sure the } \\
\text { strengths of relationships but both contribute positively to achieve credibility in services but where one } \\
\text { sub-goal is contributing to achieve a goal is a major contributor. }\end{array}$ \\
\hline
\end{tabular}

In Table I we have presented our approach in analysing the Consumer Bank case study details in which we have driven important constructs of strategy map based on the rationale/principles described in the case study. To extract a concrete list of requirements we need to do deeper analysis of the nine constructs (SM1...SM9) identified in Table I. In the analysis presented in Table II describes what these constructs mean in terms of goal analysis in RE discipline. 
TABLE II. TRANSFORMATION OF STARTEGY MAP CONSTRUCTS INTO REQUIREMENTS

\begin{tabular}{|c|c|c|}
\hline $\begin{array}{l}\text { Strategy map } \\
\text { construct }\end{array}$ & Explanation & Requirement \\
\hline SM1: Perspectives & $\begin{array}{l}\text { To describe a particular domain of concern of executives strategy } \\
\text { map uses the notion of perspective. }\end{array}$ & Perspective \\
\hline $\begin{array}{l}\text { SM2: Financial } \\
\text { perspective }\end{array}$ & $\begin{array}{l}\text { Targets related to financial perspective are precise in nature in } \\
\text { strategy map. }\end{array}$ & Quantitative goal \\
\hline $\begin{array}{l}\text { SM3: customer } \\
\text { perspective }\end{array}$ & $\begin{array}{l}\text { Customer value propositions can be described as qualitative as well } \\
\text { as quantitative targets e.g. relationship based targets are qualitative } \\
\text { targets however Service Level Agreements (SLA) can be defined } \\
\text { as quantitative targets }\end{array}$ & Qualitative goal \\
\hline $\begin{array}{l}\text { SM4: internal } \\
\text { perspective }\end{array}$ & $\begin{array}{l}\text { Strategy map identifies strategic processes as precise targets such } \\
\text { as minimise problem is a process in for which incidents must be } \\
\text { reduced to a certain limit [9]. However such a core process can be } \\
\text { supported with many sub-processes in strategy map which are } \\
\text { considered as actions to be performed to achieve process related } \\
\text { precise targets. Therefore in addition to quantitative goal (which we } \\
\text { have identified for SM2) performing action is another requirement. }\end{array}$ & $\begin{array}{l}\text { Action/activity needs to } \\
\text { be performed }\end{array}$ \\
\hline \multirow{4}{*}{$\begin{array}{l}\text { SM5: Learning \& } \\
\text { Growth (L\&G) } \\
\text { perspective }\end{array}$} & Three further aspects: & \\
\hline & $\begin{array}{l}\text { Human Capital is about stakeholders of a strategic alignment who } \\
\text { are generally considered responsible of achieving targets. So, the } \\
\text { requirement is stakeholders. }\end{array}$ & Stakeholders \\
\hline & $\begin{array}{l}\text { Information Capital refers to the portfolio of IT systems which } \\
\text { are considered as asset for an organisation. So the requirement here } \\
\text { is asset. }\end{array}$ & $\begin{array}{l}\text { Asset in terms of IT } \\
\text { systems }\end{array}$ \\
\hline & $\begin{array}{l}\text { Organisational Capital in strategy mp refers to the relationships } \\
\text { in terms of dependency among the stakeholders to achieve targets. }\end{array}$ & Dependency relationships \\
\hline $\begin{array}{l}\text { SM6: Strategic } \\
\text { intent of a } \\
\text { stakeholder }\end{array}$ & $\begin{array}{l}\text { Consumer bank has a strategic intent and Consumer Bank is a } \\
\text { stakeholder as financial service provider for a strategic alignment } \\
\text { project. Therefore capturing the concept of strategic intent of a } \\
\text { stakeholder is a requirement here. }\end{array}$ & Intention of a stakeholder \\
\hline $\begin{array}{l}\text { SM7: Rationale } \\
\text { behind a strategic } \\
\text { intent }\end{array}$ & $\begin{array}{l}\text { For Consumer Bank case study Strategy map has clearly described } \\
\text { how they intent to achieve the target. So capturing rational behind } \\
\text { strategic intent is another requirement. }\end{array}$ & Rationale \\
\hline $\begin{array}{l}\text { SM8: } \\
\text { Decomposition of } \\
\text { target }\end{array}$ & $\begin{array}{l}\text { Strategic map described how the strategic intent can be achieved } \\
\text { through the achievement of sub-objectives and further sub-sub- } \\
\text { objectives. It is clearly a goal refinement approach. }\end{array}$ & Refinement \\
\hline $\begin{array}{l}\text { SM9: Cause and } \\
\text { effect relationships } \\
\text { among the aspects }\end{array}$ & $\begin{array}{l}\text { Importantly relationships among the objectives in four perspectives } \\
\text { of strategy map must be clearly identified. Therefore cause-and- } \\
\text { effect relationships among the four perspectives are a requirement } \\
\text { here. }\end{array}$ & $\begin{array}{l}\text { Relationships among the } \\
\text { four perspectives }\end{array}$ \\
\hline $\begin{array}{l}\text { SM10: } \\
\text { relationships } \\
\text { strengths }\end{array}$ & $\begin{array}{l}\text { As we have discussed in Table I that there has been a variety of } \\
\text { relationships among the constructs described in Consumer Bank } \\
\text { case. Therefore representing all types of relationships is a } \\
\text { requirement here. }\end{array}$ & Relationships strengths \\
\hline
\end{tabular}

Table II presents an approach through which we have transformed strategy map constructs into a list of requirements that can be meaningful in requirements engineering discipline. In this approach we looked deeper into each construct of strategy map which we had first identified in Table I and attempted to understand them from RE perspective. Through this analysis approach we could find many requirements that were not highlighted in the first place - Table I. for example, learning \& growth perspective is an important aspect of strategy map in which three subaspects of learning \& growth perspective provides information about stakeholders and dependency relationships among which is very critical for a strategic alignment concept. Therefore, we are able to retrieve twelve requirements which can be considered as modelling requirements of strategic alignment when using goaloriented concepts form RE discipline. Now with these requirements (presented in the right column of Table II) we need to ask questions whether the goal modelling approaches have the ability to model these twelve requirements. We also need to find out whether one or more than one goal modelling approach can address all these requirements. 
TABLE III. A LIST OF REQUIREMENTS FOR THE CONCEPT OF STRATEGIC ALIGNMENT

\begin{tabular}{|c|c|c|}
\hline $\begin{array}{l}\text { Requirement } \\
\text { ID }\end{array}$ & Requirements Name & Description \\
\hline R1 & $\begin{array}{l}\text { Stakeholders (such as individuals, departments, systems) } \\
\text { related to the objectives in four perspectives. }\end{array}$ & $\begin{array}{l}\text { Does the goal-oriented approach support } \\
\text { modelling stakeholders relevant to the } \\
\text { concept of strategic alignment? }\end{array}$ \\
\hline $\mathbf{R 2}$ & Intentions of the stakeholders & $\begin{array}{l}\text { Does the goal-oriented approach support } \\
\text { identifying strategic intent/s associated } \\
\text { to the stakeholders? }\end{array}$ \\
\hline $\mathbf{R 3}$ & Customer value propositions (CVPs) & $\begin{array}{l}\text { Does the goal-oriented approach support } \\
\text { modelling CVPs in terms of quantitative } \\
\text { and qualitative values? }\end{array}$ \\
\hline $\mathbf{R 4}$ & Dependency relationships among the stakeholders & $\begin{array}{l}\text { Does the goal-oriented approach support } \\
\text { modelling dependency relationships } \\
\text { among the stakeholders for strategic } \\
\text { targets? }\end{array}$ \\
\hline $\mathbf{R 5}$ & Goals (quantitative) & $\begin{array}{l}\text { Does the goal-oriented approach support } \\
\text { modelling quantitative objectives in } \\
\text { strategic alignment? }\end{array}$ \\
\hline R6 & Goals (qualitative) & $\begin{array}{l}\text { Does the goal-oriented approach support } \\
\text { modelling qualitative objectives in } \\
\text { strategic alignment? }\end{array}$ \\
\hline $\mathbf{R 7}$ & Assets (Tangible and intangible) & $\begin{array}{l}\text { Does goal-oriented approach support } \\
\text { modelling assets in terms of tangible - } \\
\mathrm{S} / \mathrm{W} \text { and } / \text { or } \mathrm{H} / \mathrm{W} \text { and intangible - } \\
\text { information entities of strategic } \\
\text { alignment? }\end{array}$ \\
\hline $\mathbf{R 8}$ & Processes used to deliver financial and customer value targets & $\begin{array}{l}\text { Does the goal-oriented approach support } \\
\text { modelling processes in terms of } \\
\text { activities and tasks? }\end{array}$ \\
\hline R9 & Refinement of goals & $\begin{array}{l}\text { Does the goal-oriented approach support } \\
\text { refinement of strategic-level goals to } \\
\text { detailed-level goals? }\end{array}$ \\
\hline R10 & Rationale of strategic intent/s & $\begin{array}{l}\text { Does the goal-oriented approach support } \\
\text { facilitating rationale behind strategic } \\
\text { intent/s of the stakeholders }\end{array}$ \\
\hline R11 & $\begin{array}{l}\text { Reasoning about strategic intent/s in terms of alternatives, } \\
\text { contribution links and decomposition links. }\end{array}$ & $\begin{array}{l}\text { Does the goal-oriented approach support } \\
\text { modelling different types of } \\
\text { relationships among the goals and } \\
\text { stakeholders } \\
\text { constructs? }\end{array}$ \\
\hline $\mathbf{R 1 2}$ & Alignment perspectives & $\begin{array}{l}\text { Does the goal-oriented approach support } \\
\text { modelling different perspectives of an } \\
\text { IS? }\end{array}$ \\
\hline
\end{tabular}

These requirements in Table III act as reference point/criteria helping us to identify the level of appropriateness of goal-oriented approaches when used to model these requirements. We use these requirements as criteria to analyse goal oriented approaches from $\mathrm{RE}$ discipline.

\section{OVERVIEW OF GOAL-ORIENTED APPROACHES}

Several goal-oriented approaches have been introduced in $\mathrm{RE}$ discipline to deal with different RE problems. Some, such as $i^{*}$ [18], NFR [19] and Map [20] focus on early stage of RE in which they emphasise on the understanding of organisational environment, these approaches do not support developing specification for software development purpose. Others, such as goal-scenario coupling language, KAOS [3] and GBRAM [21] focus on later stage of RE in which temporal logic is used to specify requirements, in their cases it is highly likely that such requirements will be implemented into a software system.
Among these approaches, we select some of the widely used goal oriented approaches [7] - i*, KAOS, NFR, GBRAM and Map (map is a requirements analysis approach from Re discipline how strategy map is a strategic alignment framework from MIS discipline) and briefly discuss their concepts and constructs. Overview of these approaches can help us to decide on a most suitable goal-oriented approach to model the list of requirements provided in Table III.

\section{A. $i^{*}$ Approach}

In $i^{*}$, the central conceptual modelling construct is the actor and it is represented as an active entity that is autonomous in its actions [5, 22]. Actors as stakeholders of a system can be human, software, hardware and organizations. Key to the utility of $i^{*}$ language is the concept of dependency among stakeholders where one actor depends on another actors to achieve a goal, perform a task or furnish a resource. This kind of analysis model is called Strategic Dependency (SD) model [23]. So, in SD model, actors 
basically focus on relationships while staying silent on the activities internal to them which is actually a rationale behind strategic goals. $i^{*}$ modelling develops one coherent explanations of actor's behaviour as rationale and it is related to the actor's strategic intent for which he was dependant by other actors and altogether it is called Strategic Rationale (SR) model. $i^{*}$ uses constructs - goals, soft goals, tasks and resources to analyse the internal activities of intentional actors and facilitate reasoning among the constructs. A means-ends analysis is used to connect a task to a goal, indicating a specific way of achieving the goal. But typically there can be more than one way of achieving a goal, so in SR model a question can be asked as how else a goal can achieved.

$i^{*}$ uses task decomposition links to indicate that a task can be achieved while performing and satisfying subtasks, sub-goals, resources and/or soft goals. Tasks have contribution links to soft goals indicating how they contribute to achieve those qualities - negatively or positively with what strength.

\section{B. KAOS (Knowledge Acquisition in Automated Specification)}

KAOS is a formal goal modelling language that uses AND/OR graph to represent relationships between the goals. KAOS focus on driving functional level requirements from high-level goals. In KAOS generally agents are tagged to goals at later stage of the model [24]. As a late requirements modelling approach, KAOS focuses on formal reasoning which enables engineers to automatically drive requirements specification that satisfy high-level goals. It allows you to formally verify that the goals have been achieved. KAOS uses proof theory of temporal logic to validate the correctness of properties defined in the developed model.

\section{NFR (Non-Functional Requirements)}

NFR approach particularly focuses on modelling nonfunctional requirements such as performance, security, privacy, etc $[19,25]$. This language uses the concept of satisficed to model sufficient evidence of goal satisfaction [23]. In NFR language all the goals are represented as soft goals which are presented as quality goal graphs. High-level quality goals are decomposed into more specific goals until a satisficing solution is reached [4]. The rationale behind all the decompositions of goals is also recorded in terms of corresponding arguments.

Decomposition of each goal is guided by predefined quality goal taxonomies which represent a specific ways for achieving quality goals. NFR uses terms such as alternatives and Means-Ends to represent different ways of achieving goals in the graph. NFR also uses six qualitative labels representing goals fully satisfied, partially satisficed, unknown, conflict, partially denied and denied. These labels are placed on the sub-goals representing degree of evidence towards the satisfaction or denial of a goal. So, NFR is about developing a quality graph (by using predefined taxonomy) of early requirements in terms of soft goals only.

\section{GBRAM (Goal Based Requirements Analysis Method)}

GBRAM provides practical guidelines towards the identification and analysis of the organisational goals that help to determine system requirements to develop software systems [4, 21]. GBRAM concerns the later stage of RE in which through analysis decision about developing a software application is made. These requirements are driven from analysis of documents which may consist of enterprise policies, requirement specification of information systems and it is termed as text analysis strategy. GBRAM uses heuristic rule to identify goals from such text analysis. For example, this language searches for key words "provides" and "identify" from statements to define goals. To identify goals, GBRAM also suggests posing questions to statements such as "what goal does this statement exemplify? GBRAM is a prescriptive language that does not offer any graphical notation to represent requirements. It mainly offers identifying goals and agents in a textual form which are generally organised around system goals.

\section{E. Map}

Map presents a simple goal modelling structure during RE using two notations - intention and strategy [20]. Map claimed to be an approach that uses simple notations to address complex systems which helps analysts to understand the models easily [26]. A map provides a representation of a multi-facetted purpose on a non-deterministic ordering of intentions and strategies [20]. A Map is a graph with intentions as nodes and strategies as edges. A Map can be composed of several sections and each section is an aggregation of two kinds of intentions - source and target linked together by a strategy. An intention is 'an optative statement' that expresses what is wanted i.e. a state that is expected to be reached. A strategy is an approach, a manner, a means to achieve an intention.

\section{DISCUSSION}

Strategy map defines alignment in terms of strategic objectives in four perspectives as shown in Figure I. Therefore a suitable goal-oriented approach must conceptually be able to model strategic-level concept of alignment. In this regard our analysis suggest that most of the goal-oriented approaches are suitable to model the concept of strategic objectives as they were primarily designed to elicit the "why" aspect of a system - why means intentions and desires.

Generally all the goal-oriented approaches use the concept of goal to represent firm's strategic intent/s. Strategic intent/s can be defined as qualitative and quantitative targets therefore most of the goal modelling approaches offer notations such as soft goal and goal to represent qualitative and quantitative objectives respectively.

To develop an effective strategic alignment model it is important to understand the organisational environment, stakeholders play an important role to understand the business environment [27]. $\mathrm{i}^{*}, \mathrm{KOAS}$ and GBRAM support modelling stakeholders associated to strategic objectives however NFR and Map ignore identifying stakeholders and 
TABLE IV. EFFECTIVENESS OF GOAL-ORIENTED APPROACHES FOR MODELLING STRATEGIC ALIGNMENT

\begin{tabular}{|c|c|c|c|c|c|}
\hline $\begin{array}{l}\text { Goal Modelling } \\
\text { Modelling } \\
\text { requirements }\end{array}$ & $\mathbf{i}^{*}$ & KAOS & NFR & GBRAM & Map \\
\hline R1: stakeholders & $\sqrt{ }$ & $\sqrt{ }$ & $x$ & $\sqrt{ }$ & $x$ \\
\hline $\begin{array}{l}\text { R2: Intention of } \\
\text { stakeholders }\end{array}$ & $\sqrt{ }$ & $\sqrt{ }$ & $x$ & $\sqrt{ }$ & $x$ \\
\hline $\begin{array}{l}\text { R3: customer } \\
\text { value proposition }\end{array}$ & $\sqrt{ }$ & $\sqrt{ }$ & $\sqrt{ }$ & $\sqrt{ }$ & $\sqrt{ }$ \\
\hline $\begin{array}{l}\text { R4: Dependency } \\
\text { relationships } \\
\text { among } \\
\text { stakeholders }\end{array}$ & $\sqrt{ }$ & $x$ & $x$ & $x$ & $x$ \\
\hline $\begin{array}{l}\text { R5: Goals } \\
\text { (quantitative) }\end{array}$ & $\sqrt{ }$ & $\sqrt{ }$ & $x$ & $\sqrt{ }$ & $\sqrt{ }$ \\
\hline $\begin{array}{l}\text { R6: Goals } \\
\text { (qualitative) }\end{array}$ & $\sqrt{ }$ & $\sqrt{ }$ & $\sqrt{ }$ & $\sqrt{ }$ & $\sqrt{ }$ \\
\hline $\begin{array}{l}\text { R7: Assets (i.e. } \\
\text { tangible, } \\
\text { intangible) }\end{array}$ & $\sqrt{ }$ & $x$ & $x$ & $x$ & $x$ \\
\hline $\begin{array}{l}\text { R8: Processes (i.e. } \\
\text { tasks, activities) }\end{array}$ & $\sqrt{ }$ & $\sqrt{ }$ & $x$ & $x$ & $\sqrt{ }$ \\
\hline $\begin{array}{l}\text { R9: Refinement of } \\
\text { goals }\end{array}$ & $\sqrt{ }$ & $\sqrt{ }$ & $\sqrt{ }$ & $\sqrt{ }$ & $\sqrt{ }$ \\
\hline R10: Rationale & $\sqrt{ }$ & $x$ & $x$ & $x$ & $x$ \\
\hline $\begin{array}{l}\text { R11: Reasoning } \\
\text { (i.e. alternatives, } \\
\text { contribution link } \\
\text { and decomposition } \\
\text { links) }\end{array}$ & $\sqrt{ }$ & $\sqrt{ }$ & $\sqrt{ }$ & $\sqrt{ }$ & $x$ \\
\hline $\begin{array}{l}\text { R12: Alignment } \\
\text { perspectives }\end{array}$ & $x$ & $x$ & $x$ & $x$ & $x$ \\
\hline
\end{tabular}

predominantly their focus is on goals and their refinement during the development of a goal graph. Customer Value Proposition (CVP) is an important concept of strategy map which can be perceived as qualitative and quantitative objectives i.e. lower price and trusted advice. Soft goal and goal constructs can effectively be used to represent CVPs of strategic alignment.

As we have described in Table 1 that the relationships among the stakeholders of strategic alignment exist. Details of the case study have shown dependency among stakeholders for the delivery of strategic objectives - e.g. shareholders depend on the firm to deliver strategic financial targets however the firm depends on a specialist role to deliver CVPs [9]. In this regard $i^{*}$ appears to be the most suitable approach than others to represent strategic dependency relationships.

Strategy map also describes about assets - tangible and intangible assets. Assets mainly refer to applications and infrastructures which need to be represented when using a goal modelling approach. For this construct again $\mathrm{i}^{*}$ appears suitable which offers a construct to model resources/ assets either tangible $-\mathrm{S} / \mathrm{W}$ and $\mathrm{H} / \mathrm{W}$ and intangible - information entities.

Process is a vital construct of strategy map for strategic alignment which primarily refers to the way to achieve financial and CVPs. $i^{*}$, KAOS and Map offer notations to represent a process construct however NFR and GBRAM lack of offering a notation to represent processes. In each perspective of strategy map there are sub-objectives associated to strategic objectives which refer to the refinement/decomposition phenomenon during strategic alignment. Most of the goal-oriented approaches support refinement/decomposition of strategic goals making goaloriented approaches suitable to represent refinement concept.

In strategic alignment, one stakeholder identifies another stakeholder as responsible to deliver a target value. For example Financial Service Provider depends on financial advisor to deliver CVPs - low price and high quality products [9]. Financial advisor delivers these targets through some actions which are internal to the financial advisor. This actor's reasoning can be considered as rationale behind strategic intent/s/ which can be represented. $i^{*}$ offers a construct - actor's boundary to represent strategic rationale associated to strategic dependency model however other goal modelling approaches do not offer such concept.

Details of Consumer Bank case present different types of relationships among the objectives and sub-objectives which support firm's strategic intent/s. All the goal-oriented approaches in Table IV (except Map) support representation of different types of relationships with different meaningful construct. For example, $A N D / O R$ construct is used to indicate that the satisfaction of a goal can be achieved by satisfying all its sub-goals. Means -Ends is used to show that sole goal is sufficient enough to contribute to another goal. + 
construct represents that one goal positively influences the other goal, it is used where level of strength is un-known. Decomposition construct is used to represent decomposition of a task into more than one sub-task.

Strategic alignment phenomenon generally comprises of many aspects which must be represented. MIS discipline has consistently discussed strategic alignment in terms of different aspects. In this regard, none of the goal modelling approaches supports representation of aspects during the analysis of holistic-view of strategic information systems.

\section{CONCLUSION}

Strategic alignment is a multi-dimensional phenomenon motivating us to understand the concept from perspective view-point. Originally the concept of strategic alignment belongs to MIS discipline which must be understood in its context. The use of goal-oriented approaches has been much appreciated in RE discipline for addressing the long-standing issue of aligning IT with business effectively. In this regard several frameworks for strategic alignment have been proposed from RE community however the practical use of these frameworks has been limited. Our investigation reveals two probable lacks in the frameworks: (1) Understanding of strategic alignment concept is shallow and (2) the frameworks do not present critical analysis of the goaloriented approaches before using it to model the concept of strategic alignment. Therefore in this article we analysed the concept of strategic alignment from MIS discipline perspective and listed its important constructs that need to be modelled. Capability of five major goal-oriented approaches is assessed against the list of requirements for strategic alignment as shown in Table III. Such analysis provides insights into the level of effectiveness of goal-oriented approaches when used for modelling strategic alignment concept. Our analysis provides clear indication that $i^{*}$ is the most suitable approach to model the concept of strategic alignment embedded in strategy map. We intend to extend this assessment approach (Table III) through the integration of goal-oriented approaches addressing the more holisticview (capturing more perspectives) of strategic alignment.

\section{REFERENCES}

[1] G. Regev and A. Wegmann, "Where Do Goals Come From: The Underlying Principles of Goal-Oriented Requirements Engineering " in 13th IEEE International Conference on Requirements Engineering Paris, France, 2005.

[2] E. Yu and J. Mylopoulos, "Why Goal-Oriented Requirements Engineering," in Proceedings of 4th International Workshop on Requirements Engineering, Pisa, Italy, 1998, pp. 15-22.

[3] A. Lamsweerde, "Requirements Engineering in the Year 00: A Research Perspective " in ICSE 2000, Limerick, Ireland, 2000, pp. 519.

[4] E. Kavakli, "Goal-Oriented Requirements Engineering: A Unifying Framework," Requirements Engineering Journal, vol. 6, pp. 237-251, 2002.

[5] E. Yu, et al., "Modelling Strategic Actor Relationships to Support Intellectual Property," LNCS vol. 2224/2001, pp. 164-178, 2001.

[6] R. Matulevicius, et al., "Comaring Goal-Modelling Tools with the RE-Tool Evaluation Approach," Information Technology and Control, vol. 35, pp. 276-286, 2006.
[7] E. Kavakli and P. Loucopoulos, "Goal Driven Requirements Engineering: Evaluation of Current Methods," in Proceedings of 8th CAiSE/IFIP, Nicosia, Cyprus, 2003, pp. 1339 - 1343

[8] J. Luftman, "Key Issues for IT Executives 2004," MIS quarterly Executive, vol. 4, pp. 269 -285, 2005.

[9] R. S. Kaplan and D. P. Norton, Strategy Maps: Converting Intangible Assets into Tangible Outcomes, 2004 ed.: Harvard Business School Publishing Corporation, 2004.

[10] S. Bleistein, et al., "B-SCP: A Requirements Analysis Framework for Validating Strategic Alignment of Organizational IT Based on Strategy, Context, and Process," Information and Software Technology, vol. 49, pp. 846-868, 2006.

[11] S. N. Singh and C. Woo, "Investigating Business IT alignment Through Multi-disciplinary Goal Concepts," Requirements Engineering Journal, vol. 14, pp. 177-207, 2009.

[12] L.-H. Thevenet and C. Salinesi, "Aligning IS to Organisation's Strategy: The InStAl Method," in CAiSE 2007, pp. 203-217.

[13] P. P. Tallon, "A Process-Oriented Perspective on the Alignment of Information Technology and Business Strategy " Jounral of Management Information Systems, vol. 24, pp. 227-268, 2007-8.

[14] P. Weill, "The relationships Between Investment in Information Technology and Firm Performance: A Study of the Valve Manufacturing Sector," Information Systems Research, vol. 3, pp. 307-333, 1992.

[15] J. Luftman, Managing the Information Technology Resources: Leadership in the Information Age, First Edition ed. New Jersey: PEARSON, Prentice Hall, 2004.

[16] M. Treacy and F. Wiersema, The Discipline of Market Leaders: Cambridge, Mass, Perseus Books, 1995.

[17] W. Oh and A. Pinsonneault, "On the Assessment of the Strategic Value of Information Technologies: Conceptual and Analytical Approaches," MIS quarterly vol. 31, pp. 239-265, 2007.

[18] E. Yu, "Towards Modelling and Reasoning Support for Early-Phase Requirements Engineering," in Proceedings of the 3rd IEEE International Symposium on Requirements Engineering, Annapolis, USA, 1997, pp. 226-235.

[19] L. Chung and B. A. Nixon, Non-Functional Requirements in Software Engineering Kluwer Academic Publisher, 2000.

[20] C. Rolland and C. Salinesi, "Modelling Goals and Reasoning With Them," in Engineering and Managing Software Requirements, ed: Springer, Heidelberg, 2005, pp. 189-217.

[21] A. Anton, "Goal-Based Requirements Analysis," in 2nd IEEE International Conference on Requirements Engineering, Colorado Spring, 1996, pp. 136-144.

[22] E. Yu, "Social Modeling and $i^{*}, "$ in LNCS. vol. 5600/2009, ed: Springer Berlin / Heidelberg, 2009, pp. 99-121.

[23] J. Horkoff, "Using i* Models for Evaluation," Master's, University of Toronto, Computer Science Department, Toronto, 2006.

[24] A. Lamsweerde, "Goal-Oriented Requirements Engineering: A Roundtrip from Research to Practice," in 12th IEEE International Requirements Engineering Conference (RE'04), Kyoto, Japan, 2004, pp. 4-7.

[25] J. Mylopolous, et al., "Representing and Using Non-Functional Requirements: A Process-Oriented Approach," IEEE Transaction on Software Engineering vol. 18, pp. 483-497, 1992.

[26] C. Salinesi and M. Presso, "A Method to Analyse Changes in the Realisation of Business Intentions and Stratgies for Information System Adaptation," in Proceedings of the sixth International Enterprise Distributed Object Computing Conference, Lausanne, Switzerland, 2002, pp. 84-95.

[27] E. Yu, "Modelling Organisations for Information Systems Requirements Engineering," in IEEE International Symposium on Requirements Engineering, San Diego, CA, USA, 1993, pp. 34 - 41. 